\title{
Production of $\alpha$-Galactosidase by Aspergillus oryzae through Solid-state Fermentation and its Application in Soymilk Galactooligosaccharide Hydrolysis
}

\author{
Shankar Kapnoor and Veerappa Hanumanth Mulimani* \\ Department of Biochemistry; Gulbarga University; Gulbarga-585 106; Karnataka - India
}

\begin{abstract}
$\alpha$-Galactosidase was produced by Aspergillus oryzae on red gram plant waste-wheat bran based media in solidstate fermentation (SSF). Optimum temperature for $\alpha$-galactosidase production was $35{ }^{\circ} \mathrm{C}$ and upto $4 \mathrm{~cm}$ of bed height of substrate had no inhibitory effect on enzyme production. Hydrolysis of galactooligosaccharides in soymilk was carried out by $\alpha$-galactosidase. Optimum temperature and $\mathrm{pH}$ for the hydrolysis of raffinose and stachyose of soymilk were $55^{\circ} \mathrm{C}$ and 5.2-6.2, respectively. The enzymatic treatment for $3 \mathrm{~h}$ completely removed the raffinose oligosaccharides in soymilk. Crude extract also showed considerable amount of invertase activity.
\end{abstract}

Key words: Aspergillus oryzae, $\alpha$-galactosidase, SSF, soymilk, invertase, HPLC analysis

\section{INTRODUCTION}

$\alpha$-Galactosidase ( $\alpha$-D-galactoside galactohydrolase, E.C.3.2.1.22) is a carbohydrase, widely distributed in microorganisms, plants and animals, which catalyses the hydrolysis of $\alpha$-D-galactose from melibiose, raffinose, stachyose, verbascose and more complex polysaccharides (Dey and Pridham 1972). It is traditionally produced by the submerged fermentation technique using fungi (Rezessy-Szabo et al., 2006). In recent years, the solid-state fermentation has gained importance for the production of microbial enzymes due to economical advantages over conventional submerged fermentation (Pandey et al., 2001 Couto and Sanroman, 2005). SSF has developed in eastern countries over many centuries, and has been gaining more attention even in western countries, due to the possibility of using cheap and abundant agro-industrial waste as substrate (Holker and Lenz 2005, Krishna, 2005). Studies on the production of fungal enzymes in SSF have repeatedly shown that $\mathrm{SSF}$, in comparison with submerged fermentation $(\mathrm{SmF})$ provides higher volumetric productivities, is less prone to problems with substrate inhibition and yields enzymes with a higher temperature or $\mathrm{pH}$ stability. Also, the fermentation time may be shorter and the degradation of the enzymes by undesirable protease is minimum (Pandey et al., 1999, Holker et al., 2004). Among the various groups of microorganisms used in SSF, the filamentous fungi are most exploited because of their ability to grow on complete solid substrate and production of wide range of extracellular enzymes (Lekha and Lonsane 1994).

Among the protein sources, soy products have an excellent nutritional status and soy protein

*Author for correspondence: v_h_mulimani@ rediffmail.com 
contains enough of all the essential amino acids to meet biological requirements when consumed at the recommended level of protein intake (LeBlanc at al, 2004, Cruz and Park. 1982). The consumption of soy products, however, has been limited due to the presence of nondigestible oligosaccharides such as raffinose and stachyose, which are not eliminated by usual soy processing (Leske et al., 1993). Monogastric animals lack the ability to synthesize sufficient $\alpha$-galactosidase in their intestinal system to hydrolyze $\alpha$-galactosides present in soybeans and other legumes. Thus, these sugars (raffinose and stachyose) pass into large intestine, where the intestinal microflora acts on them, causing flatulence and gastrointestinal disturbance. These disturbances reduce both feed efficiency in monogastric animals and general consumer acceptance of soy foods (Carrena-Silva et al., 2006 and Rackis 1981). There are only few reports on the production of $\alpha$-galactosidase under SSF conditions and its possible application in reduction of galactooligosaccharides in soymilk. In the present investigation, the production of $\alpha$ galactosidase was studied in SSF by Aspergillus oryzae and its use in reduction of oligosaccharides in soymilk.

\section{MATERIALS AND METHODS}

\section{Chemicals and soybean seed cultivars}

Soybean seeds were procured from the Pulse Research Station Gulbarga, Karnataka State, India. PNPG ( $\rho$-nitrophenyl- $\alpha$-D-galactopyranoside), fructose, sucrose, raffinose, and stachyose were purchased from Sigma chemicals (USA). For the SSF process, the solid substrates red gram plant waste (RGPW), collected during harvest of red gram crop; wheat bran (WB) and other substrates were collected locally. Other media ingredients used were of analytical grade.

\section{Microorganism}

Aspergillus oryzae capable of producing extracellular $\alpha$-galactosidase was isolated by Prashanth and Mulimani (2005). The fungus was grown on potato dextrose agar (PDA) slants and stored at $4{ }^{\mathrm{OC}}$.
Fermentation media and production of $\alpha$ galactosidase under SSF conditions

Ten grams of finely chopped solid substrate which passed through sieve of $1200 \mu \mathrm{m}$ (for flour $400 \mu \mathrm{m}$ sieve was used) was taken into $250 \mathrm{ml}$ conical flasks and were moistened with mineral salt solution $(1: 2 \mathrm{w} / \mathrm{v})$ having $\mathrm{pH} 5.5$ as described previously (Shankar and Mulimani, 2007). The flasks were autoclaved at $121^{\mathrm{OC}}$ for 15 minute and cooled to room temperature. The $A$ oryzae spore suspension was prepared by adding $10 \mathrm{ml}$ of sterile distilled water containing $0.1 \%$ Tween- 80 to the extensively sporulated culture grown on PDA slants, vigorously agitated for $2 \mathrm{~min}$, and $1 \mathrm{ml}$ $\left(1 \times 10^{6}\right.$ spores $)$ of this spore suspension was used as inoculum. After inoculation, the flasks were incubated at $35{ }^{0} \mathrm{C}$ for different period of incubation.

To study the effect of temperature (flasks containing red gram plant waste and wheat bran supplemented with $20 \%$ soybean flour), the incubation temperature was varied from $20-55{ }^{\circ} \mathrm{C}$. The effect of substrate bed height on $\alpha$ galactosidase production was studied in uniform sized $(100 \mathrm{ml})$ beakers varying height from $1-5 \mathrm{~cm}$ and SSF was carried out as above.

\section{Extraction and assay of $\alpha$-galactosidase}

Enzyme extraction was carried out by adding 1:10 $(\mathrm{w} / \mathrm{v})$ dry fermented mass to sodium acetate buffer $(0.2 \mathrm{M})$ of $\mathrm{pH} 4.8$ to each flask and agitated for $1 \mathrm{~h}$ on orbital shaker at $200 \mathrm{rpm}$. The contents of the flasks were filtered through muslin cloth to separate the fermented bran and centrifuged at $5000 \mathrm{rpm}$ for $10 \mathrm{~min}$. The clear suspension, thus obtained was used for $\alpha$-galactosidase assay. Enzyme activity was assayed according to the method of Dey and Pridham (1972). One ml of reaction mixture containing $0.1 \mathrm{ml}$ of suitably diluted enzyme $+0.8 \mathrm{ml}$ of $0.2 \mathrm{M}$ acetate buffer $(\mathrm{pH} 4.8)+0.1 \mathrm{ml}$ of $2 \mathrm{mM}$ PNPG was added and incubated at $50^{\circ \mathrm{C}}$ for $15 \mathrm{~min}$. The reaction was arrested by adding $3 \mathrm{ml}$ of $0.2 \mathrm{M} \mathrm{Na}_{2} \mathrm{CO}_{3}$ solution. The absorbance was measured at $405 \mathrm{~nm}$ in a spectrophotometer (Elico Ltd, India). One unit of enzyme activity was defined as the amount of enzyme, which produced $1 \mu \mathrm{mol}$ of paranitrophenol per minute under assay 
conditions. $\alpha$-Galactosidase production under SSF was expressed as U/g dry fermented mass. Each sample was tested in triplicate.

\section{Preparation of soymilk}

Soymilk was prepared according to the method of Mulimani and Ramalingam (1995). Soybeans were ground to flour and defatted with hexane (1:1, $\mathrm{w} / \mathrm{v})$. The fat free soybean flour was suspended in 10 volumes of distilled water and boiled. Undissolved residues were separated from soymilk by centrifugation for $5 \mathrm{~min}$ at $5000 \mathrm{rpm}$. The supernatant, which contained soymilk, was stored at $4{ }^{\circ} \mathrm{C}$ until further use.

\section{Estimation of oligosaccharides in soymilk}

Fifteen milliliter of soymilk was poured into $35 \mathrm{ml}$ absolute ethyl alcohol and centrifuged at $6000 \mathrm{rpm}$ for $15 \mathrm{~min}$ at $37{ }^{0} \mathrm{C}$. The centrifugate was concentrated and redissolved in $15 \mathrm{ml}$ distilled water. The amounts of sucrose, raffinose and stachyose were estimated by the method of Tanaka et al., (1975). TLC was prepared by dissolving $30 \mathrm{~g}$ of cellulose $-\mathrm{G}$ powder in $45 \mathrm{ml}$ of double distilled water to obtain $0.2 \mathrm{~mm}$ thick plates and air-dried. The hydrolyzed soymilk was loaded $(5 \mu \mathrm{l}$ of syrup) in triplicate with standard sugars (sucrose, raffinose and stachyose). Sample loaded TLC plate was developed by using solvent system npropanol: ethylacetate: water $(6: 1: 3)$ and air-dried. After the run, one part of TLC (where standard solutions were loaded) was sprayed with spraying reagent (1\% $\alpha$-naphthol in $90 \mathrm{ml}$ of $95 \%$ ethanol containing $10 \%$ orthophosphoric acid) and the other part (where hydrolyzed samples are loaded) was covered with paper while spraying. Then the plates were air-dried and kept in hot air oven at $100{ }^{0} \mathrm{C}$ for $10-15$ minutes. Corresponding to the detected spot in the unsprayed region of TLC, the plate was scraped and dissolved in $3 \mathrm{ml}$ of water and after keeping for $12 \mathrm{~h}$ at room temperature, the solution was filtered through Whatman No.1 filter paper. One milliliter of filtrate was taken and $1 \mathrm{ml}$ of $0.02 \mathrm{M}$ thiobarbituric acid was added, followed by addition of $1 \mathrm{ml}$ of concentrated hydrochloric acid. The reaction mixture was incubated in boiling water bath for $6 \mathrm{~min}$ and cooled in ice-cold water. The yellow color developed was read at $432.5 \mathrm{~nm}$ in a spectrophotometer, (Elico, India) and concentrations of the constituent carbohydrates were calculated with working standards.

\section{Separation of oligosaccharides by HPLC}

High performance liquid chromatography (HPLC) analysis was performed with a Shimadzu HPLC (Shimadzu Corporation, Japan), equipped with LC 10ATVP pump and refractive index detector. Sample injection was via a Rheodyne injector equipped with a $20 \mu \mathrm{l}$ sample loop. Carbohydrates were separated on a Phenomenex Bondclone $10 \mu$ CHO column (column of size $300 \mathrm{x} 3.9 \mathrm{~mm}$ ). The mobile phase consisted of acetonitrile:water $(70: 30, \mathrm{v} / \mathrm{v})$. The flow rate was fixed at $1 \mathrm{ml} / \mathrm{min}$. Chromatographic data were collected and plotted using Class-VP 6.1 software. The peak identification of the chromatographs was done by comparing the retention times with the standards.

\section{Treatment of soymilk by enzyme}

The enzymatic treatment of soymilk was performed by taking $4 \mathrm{ml}$ of soymilk (pH 6) and 4 units of $\alpha$-galactosidase and incubated for $3 \mathrm{~h}$ at different temperatures and $\mathrm{pH}$. At the end of the incubation period, the reaction was arrested by adding $0.2 \mathrm{ml}$ of $0.3 \mathrm{M}$ barium hydroxide and 0.2 $\mathrm{ml} 0.18 \mathrm{M}$ zinc sulfate and the precipitated protein was removed by centrifugation. The galactose liberated was estimated as reducing sugar (Nelson, 1944). In a typical experiment, $50 \mathrm{ml}$ of soymilk was mixed with 50 units of $\alpha$-galactosidase and incubated at $50^{\circ \mathrm{C}}$ for $3 \mathrm{~h}$ with occasional shaking. The reaction was stopped by placing the mixture in a boiling water bath for $15 \mathrm{~min}$, followed by the addition of $2 \mathrm{ml}$ of $0.2 \mathrm{M}$ barium hydroxide and 2 $\mathrm{ml}$ of $0.18 \mathrm{M}$ zinc sulfate. The precipitated protein was removed by centrifugation and the supernatant thus obtained was subjected to TLC and HPLC as described above.

\section{RESULTS AND DISCUSSION}

\section{Production of $\alpha$-galactosidase under solid- state fermentation}

From Figure 1, it was evident that red gram plant waste (RGPW) with wheat bran $(1: 1$, w/w) supplemented with soybean flour $(20 \%)$ served as the best substrate for $\alpha$-galactosidase production by $A$. oryzae. Rice flour, corn flour and wheat flour were less effective for the enzyme production. Low enzyme titers in these flours could be due to stickiness of the substrate that might have prevented the penetration of mycelia deep into the medium, hence affected the growth 
as well as enzyme production. After supplementation of $20 \%$ soybean flour, there was increase in $\alpha$-galactosidase synthesis, which could be attributed to the presence of raffinose oligosaccharides (the natural substrates for $\alpha$ galactosidase). During the study of $\alpha$ galactosidase biosynthesis from Penicillin sp in SSF, higher enzyme yield was observed when wheat bran, soybean meal and beet pulp were mixed in appropriate quantity (Wang et al., 2004). In another study by Annunziato et al., (1986), the defatted soy flour was found as potential substrate for $\alpha$-galactosidase production by a strain of $A$. oryzae in SSF. Liu et al., (2007) reported that maximum activity of $\alpha$-galactosidase was observed when wheat bran $(83.2 \%)$ was used along with soybean meal $(16.64 \% \mathrm{w} / \mathrm{w})$ in SSF by a novel strain of $A$. foetidus ZU-G1. Figure 1 also showed that the maximum $\alpha$-galactosidase occurred on $4^{\text {th }}$ day of incubation which was shorter compared to $\alpha$-galactosidase produced from thermophilic fungus Humicola sp. which required 6 days to attain maximum enzyme production (Kotwal et al., 1998)

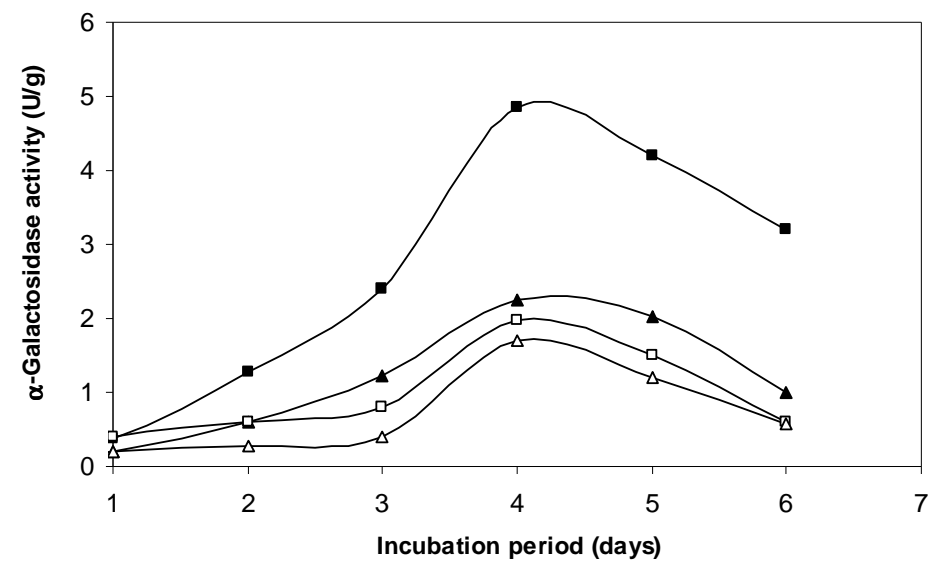

Figure 1 - Production of $\alpha$-galactosidase by Aspergillus oryzae in SSF using red gram plant waste + wheat bran + soy flour $(-\mathbf{-}-)$; rice flour $(-\mathbf{\Delta}---)$; corn flour $(-\square-)$;) and wheat flour $(-\Delta-)$.

\section{Effect of temperature on $\alpha$-galactosidase production}

Table 1 shows the optimum temperature for $\alpha$ galactosidase production under SSF conditions by A. oryzae. Beyond $35{ }^{\circ} \mathrm{C}$, a decrease in enzyme production was observed (data not shown). Fungi can grow over a wide range of temperatures, such as $20-55{ }^{\circ} \mathrm{C}$, which could be exploited against the inhibition of growth, or enzyme production due to metabolic heat liberated in SSF. Temperature below $25^{\circ \mathrm{C}}$ resulted minimum enzyme production (data not shown), which might be attributed to delay in the spore germination due to low temperature. It has been reported that a short elevation of temperature helps to promote the fungal spores to germinate quickly (Wang et al., 2004).

Table 1 - Effect of some parameters on production and optimum conditions for hydrolysis of galactooligosaccharides in soymilk by Aspergillus oryzae $\alpha$-galactosidase.

\begin{tabular}{llc}
\hline & \multicolumn{1}{c}{ Parameters } & Optimum condition \\
\hline a. & Effect of temperature on $\alpha$-galactosidase production in SSF & $35^{0} \mathrm{C}$ \\
b. & Effect of substrate bed height on $\alpha$-galactosidase production & $4 \mathrm{~cm}$ \\
c. & Effect of pH on hydrolysis of raffinose and stachyose in soymilk & $5.2-6.2$ \\
d. & Effect of temperature on hydrolysis of raffinose and stachyose in soymilk & $55^{0 \mathrm{C}}$ \\
\hline
\end{tabular}


Effect of bed height on a-galactosidase production

Bed height of the substrate consisting of RGPW + WB (1:1), supplemented with $20 \%$ soybean flour was varied from $1-5 \mathrm{~cm}$. Table 1 showed that the optimum production of $\alpha$-galactosidase was up to $4 \mathrm{~cm}$, and higher bed height resulted in decrease in enzyme production. This could be attributed to the inhibition of growth of microorganism due to metabolic heat generated during the fermentation. In SSF, aeration has essential functions: oxygen supply for aerobic metabolism, and removal of $\mathrm{CO}_{2}$, heat, water vapors and volatile components produced during metabolism. Aeration also has very important effect on hydration properties in SSF (Gervais and Molin, 2003). Liu et al., (2007) used different layer of pledges on $\alpha$-galactosidase production. The result revealed that six layers of pledges were better than eight layers for enzyme production.

\section{Hydrolysis of oligosaccharides from soymilk}

Effect of $\mathrm{pH}$ on hydrolysis of raffinose and stachyose in soymilk

The extracellular $\alpha$-galactosidase produced under SSF condition exhibited the optimum $\mathrm{pH}$ of 5.26.2 for the hydrolysis of raffinose and stachyose present in soymilk (Table 1). The enzyme worked effectively at this broad $\mathrm{pH}$ range $(\mathrm{pH}$ of natural soymilk was 6.3 and that of commercial soymilk 6.1) to hydrolyze the raffinose and stachyose of soymilk, obviating the need for $\mathrm{pH}$ adjustment. $\alpha$ Galactosidase from the fungi Mortierella vinacea (Thananunkul et al., 1976) and guar (Cyanopsis tetragonolobes) exhibited maximum hydrolysis at $\mathrm{pH}$ of 4.0-4.5 and 5.0, respectively (Shivanna and Ramakrishna, 1989).

Effect of temperature on hydrolysis of raffinose and stachyose in soymilk

The enzyme showed maximum activity at $55^{\circ \mathrm{C}}$ for the hydrolysis of raffinose and stachyose of soymilk (Table 1). This was in comparison to $\alpha$ - galactosidase from Mortierella vinacea, which exhibited maximum hydrolysis of raffinose and stachyose at $50^{\circ \mathrm{C}}$ (Thananunkul et al., 1976). Kotwal et al., (1998) reported maximum hydrolysis of these sugars at $50^{\circ \mathrm{C}}$. The advantage of using $A$. oryzae $\alpha$-galactosidase could be that since it has higher temperature optima $\left(50-60^{\circ \mathrm{C}}\right)$, the contaminants during the enzyme treatment of soymilk would be restricted to thermophilic microorganisms. Figure 2A shows TLC separation pattern of raffinose oligosaccharides in soymilk. Soymilk sample initially contained $625 \mathrm{mg}$ of total oligosaccharides per $100 \mathrm{ml}$ of soymilk, out of which $481 \mathrm{mg}$ of stachyose and $144 \mathrm{mg}$ of raffinose were the main constituents. In the enzymatic treatment of oligosaccharides in soymilk, the $\alpha$-galactosidase ( $50 \mathrm{U}$ ) was incubated with soymilk at different incubation period, i.e., $0.5-3 \mathrm{~h}$. The $3 \mathrm{~h}$ incubation resulted more than $95 \%$ of hydrolysis, and after 1 and 2h, 75 and 93 $\%$ degradation of these sugars 0Ccurred (Fig. 2B). The interesting result was that that around $90 \%$ oligosaccharides hydrolysis was observed within $2.5 \mathrm{~h}$. The hydrolysis after $2 \mathrm{~h}$ was very slow probably due to substrate depletion; it could also be due to the product inhibition (Sugimoto and Van buren 1970). Thananunkul et al., (1976) tested the ability of $M$. vinacea in three different forms (undisrupted, disrupted and entrapped) for the hydrolysis of raffinose and stachyose from soymilk and found that mycelial homogenate showed highest hydrolysis ratio (i. e., 33\%) in $6 \mathrm{~h}$. Partially purified $\alpha$-galactosidase from A. saitoi completely decomposed raffinose and stachyose into their monomers after $3 \mathrm{~h}$ of incubation (Sugimoto Van buren 1970). HPLC analysis of the enzyme sample treated for $2 \mathrm{~h}$ indicated the complete hydrolysis of raffinose and more than $85 \%$ hydrolysis of stachyose (Fig. 3). The extracellular enzyme preparation showed invertase activity (data not shown). Figure 3B indicated the presence of sucrose peak in raw soymilk sample. 

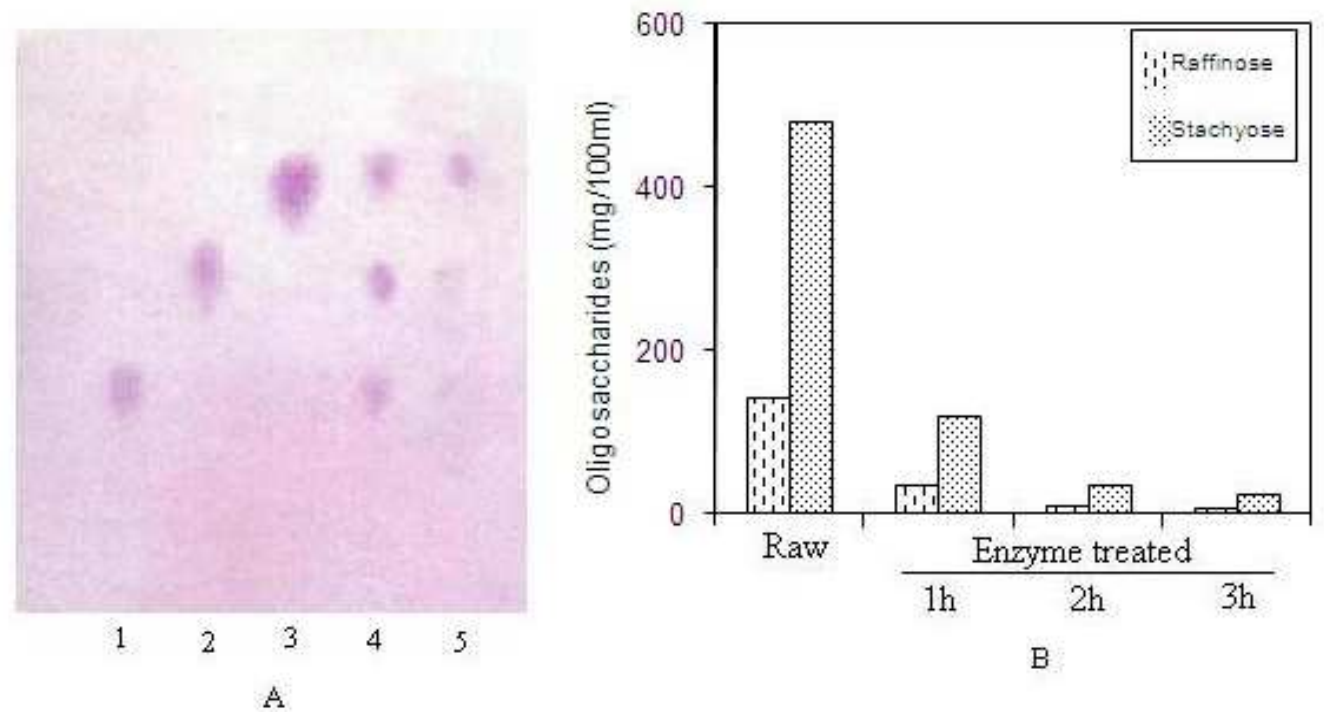

Figure 2 - A. TLC separation pattern of galactooligosaccharides in soymilk (lane: 1, 2 and 3, standard sugars, stachyose, raffinose and sucrose; lane 4: untreated soymilk and lane 5: After $3 \mathrm{~h}$ incubation with $\alpha$-galactosidase) B. Percentage hydrolysis after $1 \mathrm{~h}, 2 \mathrm{~h}$ and $3 \mathrm{~h}$ incubation with $\alpha$-galactosidase from Aspergillus oryzae.

After the treatment with crude enzyme solution, the sucrose peak almost disappeared, indicating the presence of invertase activity in the crude extract (Fig. 3C.). The advantage of invertase activity is that it aids in hydrolyzing the accumulated sucrose to glucose and fructose and thereby increases the sweetness and palatability of soymilk (Mulimani and Ramalingam, 1995). A. fumigates secreted invertase ( $\beta$-fructofuranosidase) and $\alpha$-galactosidase, which were able to hydrolyze raffinose oligosaccharides (Rezende et al, 2005). Viana et al., (2006) treated the soymilk with extracellular $\alpha$-galactosidase from Debaryomyces hansenii UFV-1 and found that after $4 \mathrm{~h}$ at $60^{\circ} \mathrm{C}$, the amount of stachyose and raffinose was reduced by $100 \%$. Song and Chang, (2006) treated pinto bean flour with crude $\alpha$-galactosidase from $A$. awamori NRRL from wheat bran based substrate with soy tofu whey. After $2 \mathrm{~h}$ of incubation, complete hydrolysis of raffinose oligosaccharides was observed. Similarly, $\alpha$-galactosidase from a thermophilic fungus Humicola sp hydrolyzed $\alpha$ galactosides from soymilk completely within $2 \mathrm{~h}$ of incubation period (Kotwal et al., 1998).
There are some reports of using genetically modified organisms for soymilk treatment (Mital and Steinkrous, 1975; LeBlanc et al., 2004). The usage of genetically modified organisms might rely on the still controversial decision about the acceptability in nutrition and other food preparations. In the present studies, A. oryzae capable of producing $\alpha$-galactosidase was used and could be considered as the excellent host for the safe production of harmless products (Barbasgaard et al., 1992). Among the various microbes used in food industry, fungi with GRAS status as enzyme producers have many advantages. The fungus $A$. oryzae having GRAS status produced $\alpha$ galactosidase in inexpensive medium under SSF. The properties of $\alpha$-galactosidase described here, especially the broad $\mathrm{pH}$ and temperature optima for the hydrolysis of galactooligosaccharides in soymilk suggested its possible application to remove the flatulence-inducing compounds from soymilk and the proCess of enzymatic treatment could have potentiality of commercialization. 


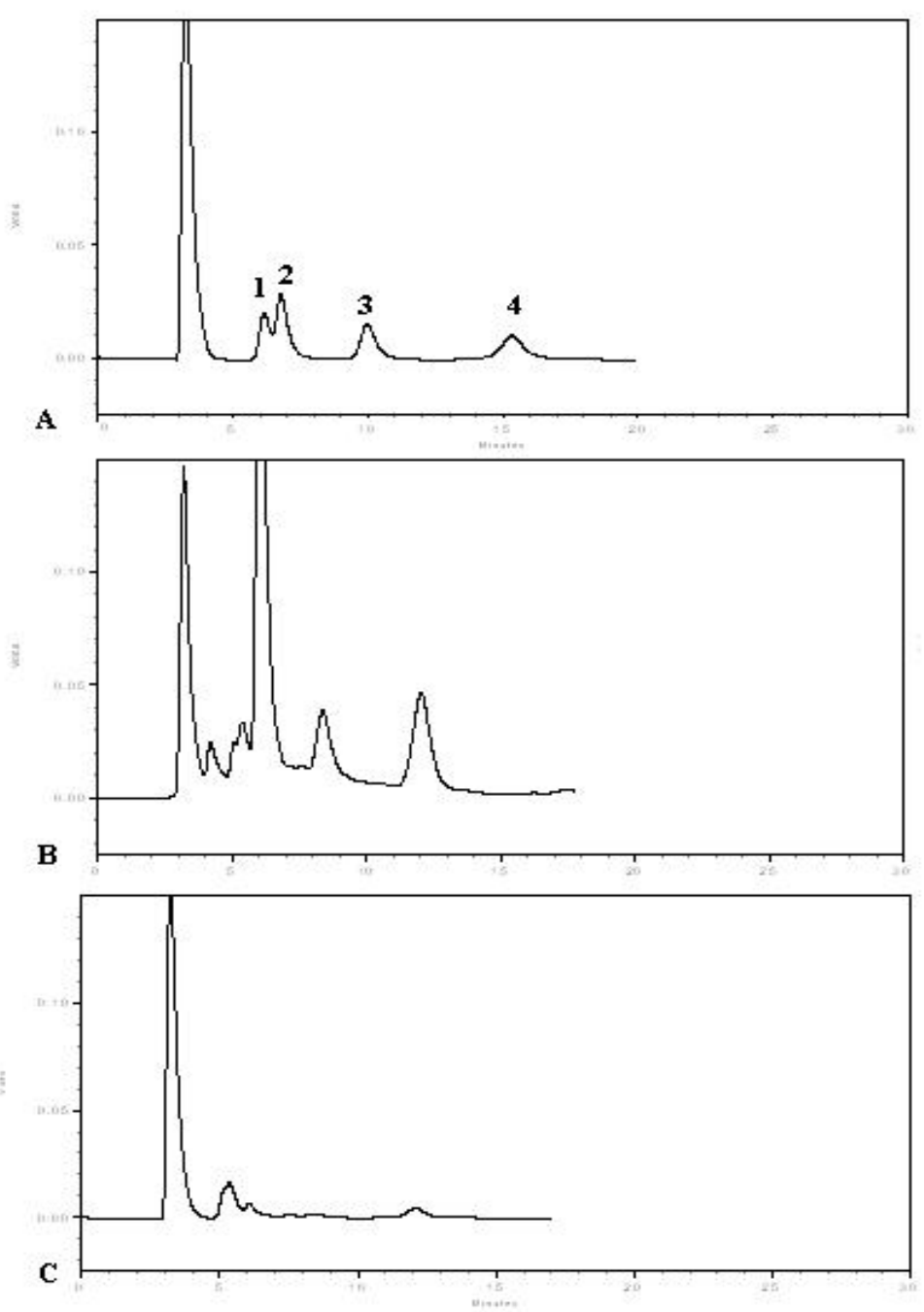

Figure 3 - HPLC separation pattern of raffinose oligosaccharides of soymilk before and after treatment with Aspergillus oryzae $\alpha$-galactosidase produced under SSF

A. Standard Sugars (1. Galactose 2. Sucrose 3. Raffinose 4. Stachyose)

B. Soymilk before enzyme treatment

C. Soymilk after treatment with $\alpha$-galactosidase.

\section{ACKNOWLEDGMENT}

One of the authors (Shankar S K) acknowledges Council of Scientific and Industrial Research (CSIR), New Delhi for awarding Senior Research Fellowship (SRF) for Ph.D. work.

\section{REFERENCES}

Annunziato, M.E; Mohaney, R. R; Mudgett. (1986), Production of $\alpha$-galactosidase from Aspergillus oryzae grown in solid- state culture. J. Food. Sci., 51, 1370-1371.

Barbasgaard; Hansen, H.P; Diderichsen, B. (1992), On the safety of Aspergillus oryzae: a review. Appl. Microbiol. Biotechnol., 36, 569-572.

Carrera-Silva, E. A; Silvestroni, A; LeBlanc, J. G; Piard, J. -C; Savoy, De Giori G; Sesma, F. (2006), A thermostable $\alpha$-galactosidase from Lactobacillus fermentum CRL722: genetic characterization and main properties. Curr. Microbiol., 53, 374-378.

Couto, S. R. and Sanroman, M. A. (2005), Application of solid-state fermentation to food industry- a review. J.Food. Eng, 22, 211-219. 
Cruz, R. and Park, Y.K. (1982), Production of fungal $\alpha$ galactosidase and its application to the hydrolysis of galactooligosaccharides in soybean milk. J. Food Sci., 47, 1973-1975.

Dey, P. M. and Pridham, J. B. (1972), Bi0Chemistry of $\alpha$-galactosidase: Adv. Enzymol., 36, 911-930.

Gervais, P. and Molin, P. (2003), The role of water in solid-state fermentation. BiOChe. Eng. Journal, 13 (23): 85-101. [doi:10.1016/S1369-703X(02)00122-5].

Holker, U. and Lenz, J. (2005), Solid-state fermentation- are there any biotechnological advantage? Current. Opin. Microbiol., 8, 201-306.

Holker, U; Hofer, M; Lenz, J. (2004), Biotechnological advantages of laboratory-scale solid-state fermentation with fungi (Mini review). Appl. Microbiol. Biotechnol., 64, 175-186.

Kotwal, S. M; Gote, M. M; Sainkar, S. R; Khan, M. I; Khire, J. M. (1998), Production of $\alpha$-galactosidase by thermophilic fungus Humicola $s p$. in solid- state fermentation and its application in soymilk hydrolysis. PrOCess. BiOChem., 33, 337-343.

Krishna, C. (2005), Solid-state fermentation system An overview. Critic. Rev. Biotechnol., 25, 1-30.

LeBlanc, J; Guy; Aurelio, S; Cristelle, C; Vincet, J; Graciela; Savoy, D. Giori; Jean-Christopher, P. and Fernando, S. (2004), Reduction of non -digestible oligosaccharides in soymilk: application of engineered lactic acid bacteria that produce $\alpha$ galactosidase. Gen. Mol. Res., 3, 432-440.

Lekha, P. K. and Lonsane, B. K (1994), Comparative titres 10Cation and properties of tannin acyl hydrolase by Aspergillus niger PKL104 in solid-state, liquid surface and submerged fermentation. PrOCess. BiOChem., 29, 497-503.

Leske, K. L; Jevne, G. J. and Coon, C. N. (1993), Effect of oligosaccharide additions on nitrogen corrected true metabolizable energy of soy protein concentrate. Poult. Sci., 72, 664-668.

Liu, Cai-qin; Chen, Qi-he; Cheng, Qian-jun; Wang, Jinling; He, Guo-qing. (2007), Effect of cultivating conditions on $\alpha$-galactosidase production by a novel Aspergillus foetidus ZU-G1 strain in solid-state fermentation. J. Zhejiang. Univ. Sci. B. 8, 371-376.

Mital, B. K. and Steinkraus. (1975), Utilization of oligosaccharides by lactic acid bacteria during fermentation of soymilk. J. Food. Sci, 40, 114-118.

Mulimani, V.H. and Ramalingam (1995), Enzymic hydrolysis of raffinose and stachyose present in soymilk by crude $\alpha$-galactosidase from. Gibberella fujikuroi. BiOChem. Mol. Biol. Int., 36, 897-905

Nelson, N. A. (1944), Photometric adaptation of the Somogi method for the determination of glucose. $J$. Biol. Chem., 153, 375-378.

Pandey, A; Selvakumar, P; S0Ccal, C. R; Poonam, N.(1999), Solid-state fermentation for the production of industrial enzymes. Curr. Sci., 77, 149- 169.

Pandey, A; S0Ccol, C. R; Nigam, P. and S0Ccol, V. T. (2001), Biotechnological potential of agro-industrial residues. I: sugar cane bagasse. Bioresource Technol., 74, 69-80.

Prashanth, S. J. and Mulimani, V.H. (2005), Soymilk oligosaccharide hydrolysis by Aspergillus oryzae $\alpha$ galactosidase immobilized in calcium alginate. PrOCess. BiOChem., 40, 1199-1205.

Rackis, J. J. (1981), Flatulence caused by soya and its control through proCessing. Journal of Am. Oi.l Chem. SOC., 58, 503-509.

Rezende, S.T; Guimaraes V. M; Castro, M; Rodrigues and Felix, C. R. (2005), Purification and Characterization of an a-galactosidase from Aspergillus fumigatus. Braz. Arch. Biol. Technol. 48, 195-202.

Rezessy-szabo, J. M; Nguye, Q.D; Christophe, A.H; Gyongyi, B; Marc, H.C. (2006), A thermostable $\alpha$ galactosidase from the thermophillic fungus Thermomyces lanuginosus CBS 395.62/b Purification and characterization. BiOChem. Biophys. Acta. 1770, $55-62$.

Shankar, S K. and Mulimani, V. H. (2007), $\alpha$ Galactosidase production by Aspergillus oryzae in solid-state fermentation. Bioresou. Technol., 98, 958961.

Shivanna, B.D. and Ramakrishna, M. (1989), $\alpha$ Galactosidase from germinating guar Cyamopsis tetragonolobus). J. Biosci., 9, 109-116.

Song, D. and Chang, Sam. K. C. (2006), Enzymatic degradation of oligosaccharides in Pinto bean flour. $J$. Agric. Food. Chem., 54, 1296-1301.

Sugimoto, H. and Van buren, J. P. (1970), Removal of oligosachharides from soymilk by an enzyme from Aspergillus sioti. J. Food Sci., 35, 655-660.

Tanaka, M; Thananunkul, D; Lee, T.C; Chichester, C.O. (1975), A simplified method for the quantitative determination of sucrose, raffinose and stachyose in legumes. J. Food. Sci.40, 1087-1088.

Thananunkul, D; Tanaka, M; Chichester, C.O. and Lee, T.C. (1976), Degradation of raffinose and stachyose in soybean milk by $\alpha$-galactosidase from Mortirella vinacea. Entrapment of $\alpha$-galactosidase within polyacrylamide gel. J. Food Sci., 41,173-175.

Viana, P. A; De Rezende, S. T; Marques, V. M; Trevizano, L. M; Passos, F. M. L; Oliveira, M. G. A; Bemqyerer, M. P; Oliveira, J. S. and Guimaraes, V. M. (2006), Extracellular $\alpha$-galactosidase from Debaryomyces hansenii UFV-1 and its use in the hydrolysis of raffinose oligosaccharides. J. Agric. Food Chem., 54, 2385-2391.

Wang, C. L; Li, D.F; Lu, W.Q; Wang; Lai, C.H. (2004), Influence of cultivation conditions on the $\alpha$ galactosidase biosynthesis from a novel strain of Penicillium sp. in solid-state fermentation. Lett. Appl. Microbiol., 39, 369-375.

Received: November 26, 2007; Revised: May 15, 2008, Accepted: June 07, 2009. 